\title{
Biogas Production from Various Typical Organic Wastes Generated in the Region of Cantabria (Spain): Methane Yields and Co-Digestion Tests
}

\author{
Carlos Rico1, Rubén Diego ${ }^{2,3}$, Agustín Valcarce², José Luis Rico4 \\ ${ }^{1}$ Department of Water and Environment Science and Technologies, University of Cantabria, Santander, Spain \\ ${ }^{2}$ Teican Medioambiental, Boo de Piélagos, Cantabria, Spain \\ ${ }^{3}$ Department of Business Administration, University of Cantabria, Santander, Spain \\ ${ }^{4}$ Department of Chemical and Process Engineering Resources, University of Cantabria, Santander, Spain \\ Email: ricoc@unican.es, rdiego@teican.com
}

Received $* * * * 2014$

Copyright (C) 2014 by authors and Scientific Research Publishing Inc.

This work is licensed under the Creative Commons Attribution International License (CC BY).

http://creativecommons.org/licenses/by/4.0/

c) (i) Open Access

\section{Abstract}

Batch trials were carried out to determine the methane potential yields of some typical organic wastes generated in the region of Cantabria (Spain): cocoa shell, cheese whey and sludges from dairy industry. Anaerobic co-digestion trials of these wastes with dairy manure were also investigated in batch at $35^{\circ} \mathrm{C}$. Cheese whey obtained similar methane yields than dairy manure, between 17.5 and $19.3 \mathrm{~L} \mathrm{CH}_{4} \mathrm{~kg}^{-1}$ cheese whey compared with $18.0 \mathrm{~L} \mathrm{CH}_{4} \mathrm{~kg}^{-1}$ manure. Methane yields of various sludge samples collected from wastewater treatment facilities of dairy industries were influenced by its origin. Sludge samples from fat separation devices were the most productive in terms of specific methane yields compared with biological sludge from an aerobic reactor. Sludge samples from fat separator reached specific methane productivities of 350 and $388 \mathrm{~L} \mathrm{CH}_{4} \mathbf{k g}^{-1} \mathrm{VS}^{-}$ (10.5 and 24.1 $\mathrm{L} \mathrm{CH}_{4} \mathrm{~kg}^{-1}$ sludge), whereas biological sludge yielded $125 \mathrm{~L} \mathrm{CH}_{4} \mathrm{~kg}^{-1} \mathrm{VS}\left(12.6 \mathrm{~L} \mathrm{CH}_{4}\right.$ $\mathrm{kg}^{-1}$ sludge). The methane potential of sludge samples was influenced by solids content. Cocoa shell resulted to be an interesting waste for anaerobic digestion due to its high VS content, yielding $195 \mathrm{~L} \mathrm{CH}_{4} \mathrm{~kg}^{-1}$ cocoa shell. It is a waste that can considerably improve methane yields in anaerobic co-digestion with dairy manure. However, at proportions of $10 \%$ cocoa shell, the process was hindered by hydrolysis of particulate matter. Anaerobic digestion at higher temperatures (thermophilic range) could be a better option for this kind of waste. Co-digestion of $5 \%$ cocoa shell with $35 \%$ dairy sludge and $60 \%$ dairy manure resulted in $80.5 \%$ higher methane production compared to anaerobic digestion of dairy manure alone. 


\section{Keywords}

\section{Cheese Whey, Co-Digestion, Cocoa Shell, Dairy Sludge, Manure}

\section{Introduction}

Cantabria is a small region in the Northern Coast of Spain that has a bovine population of around 280,000 livestock units (mainly milk) which generate about 4.5 million tons of semi-liquid manure ( $7 \%$ - 14\% TS) annually. Much larger dairy farms have become more common since 1990, resulting in greater awareness and concern for the proper management of manure. Typical disposal methods for animal manure allow for the emission of methane, ammonia, particulate matter, unpleasant odors, volatile organic compounds and a variety of other air pollutants, which can damage the environment and pose risks to animal and human health [1] [2]. Moreover, when manure is not properly managed it can cause severe environmental problems such as eutrophication of water bodies due to its high organic matter, nitrogen and phosphorous concentrations [3] [4]. Anaerobic digestion of animal manure is a well-known technology [5] that allows converting these concerns in two valuable products: biogas, a renewable fuel and the digested manure, with improved fertilizer characteristics [6]. Refining digested manure into concentrated fertilizers can also stimulate the distribution of surplus nutrient to other zones that have nutrient deficit, reducing environmental impacts caused by uncontrolled manure land application. On the other hand, anaerobic digestion also fulfills the goal of reducing greenhouse gas (GHG) emissions [7]. During storage in manure pits, the submerged manure generates methane, a GHG with 21 times the global warming potential of carbon dioxide, according to the Intergovernmental Panel on Climate Change (IPCC). Methane emissions can be avoided by processing manure in biogas facilities where methane can be recovered and converted in green energy.

Application of anaerobic digestion can be extended for almost any kind of organic waste or biomass, such as the biodegradable part of municipal solid waste, sewage sludge, wastes and wastewaters from food industry, energy crops, etc. In the case of organic wastes and wastewaters, many of them are also sources of methane emissions if not managed properly [8]. However, anaerobic digestion of organic wastes can be hindered due to the presence of toxic compounds for anaerobic microorganism [9]. High organic content and low buffer capacity can also lead to inhibitory effects on anaerobic digestion due to acidification or formation of intermediate toxic compounds, as has been reported for slaughterhouse waste and cheese whey [10] [11]. In general, the characteristics of dairy manure and organic wastes are opposite for anaerobic digestion. Whereas methane yields for some organic wastes can reach several hundred cubic meters per ton of waste [12] [13], the fermentation of manure alone results in lower methane yields due to the high water content and moderate anaerobic biodegradability of about $45 \%$ - 50\% [14]. However, the high water content and buffer capacity of manure, as well as trace elements, have a positive effect on process stability. For this reason, most of the biogas plants are operated today by co-digestion (anaerobic digestion in which two or more substrates are mixed) of manure together with organic wastes [15]. Dilution of toxic compounds, increased load of biodegradable organic matter, improved balance of nutrients, synergistic effect of microorganisms and better biogas yields have been reported as potential benefits for the co-digestion process [16]. Therefore, anaerobic co-digestion has become a good strategy for both the waste treatment and the production of renewable fuels.

In the last decades, the anaerobic digestion process has widely developed all across the majority of the European countries, due to new trends to promoting the production of biogas from agro-industrial wastes. The EUcountries where the agricultural biogas plants are most developed are Germany, Denmark, Austria and Sweden [6]. However, in spite of environmental and socio-economic benefits of biogas plants, agro-industrial anaerobic digestion technology has not developed in Spain mainly due to the low price paid for electric energy produced by biogas plants (less than $0.15 €$ per KWh-el). According to Alfonso et al. [17], Cantabria has an available potential of 61 million $\mathrm{m}^{3}$ per year of agro-industrial biogas. This volume of biogas would represent an electricity production of $139 \mathrm{GWh} /$ year in combined heat and power (CHP) production systems, and the $5 \%$ of total electricity consumed in 2012 in Cantabria. According to the Spanish Statistical Office, the food industry sector represents $15.4 \%$ of total industry volume of Cantabria. It generates a variety of organic wastes and other byproducts that could be used as biomass energy sources. In terms of amount, the most important are those derived 
from the manufacture of dairy products, canned fish and other products from cocoa, chocolate, coffee, bakery and pastry industry. At present, many of these wastes and by-products have no market and are not receiving biotreatments for resources recovery. For instance, only $42.6 \%$ of 15,600 tons per year of cheese whey produced in the region were managed in 2005, but mainly as animal feed [18]. In 2011, 16,900 tons of cheese whey were produced in Cantabria with similar management strategies.

In the present work, the methane potential of various organic wastes produced in Cantabria has been determined. The aim of this study was not only to determine individual methane yields, but also to study the synergies of co-digestion with dairy manure.

\section{Methods}

\subsection{Substrates and Inoculum}

Four typical organic wastes produced in Cantabria were tested to determine their methane potential yields: cocoa shell, cheese whey, sludge from dairy industry and dairy manure. Cocoa shell (CS), a solid waste, was proceeded from a dairy factory that manufactures dairy milk chocolate products. It was crushed to reduce particle size. Three samples of sludge from dairy industry were taken from two different factories. The sludge samples were collected from the wastewater treatment facilities. Two of the sludge samples (SL1 and SL2) were taken from the fat separator previous to biological treatment of two different factories. The other sludge sample was the dewatered biological sludge (DSL1) taken from the factory where SL1 was collected. The biological sludge proceeded from the wastewater aerobic reactor and was dewatered by centrifuging. Cheese whey (CW) samples originated from three different cheese production factories. Dairy manure (M) sample proceeded from an intensive dairy farm. Liquid and semi-liquid substrates (SL, DSL, CW and M) were stored at $4^{\circ} \mathrm{C}$ prior to use.

The anaerobic inoculum was collected from a pilot CSTR digester that processed the screened liquid fraction of dairy manure [19]. To ensure degradation of remaining degradable organic matter in inoculums, it was stored, allowing the release of gas at $35^{\circ} \mathrm{C}$ for a week. Characteristics of organic wastes and inoculum are shown in Table 1.

\subsection{Experimental Design}

Two types of test were performed, a Biochemical Methane Potential (BMP) and co-digestion experiment tests. The first was made to determine the ultimate methane yields of the different wastes alone. The second was made to assess different co-digestion ratios of manure with several mixtures of wastes. Both experiments were performed in batch.

All the tests were performed in triplicate using 500-mL serum bottles capped with rubber septum sleeve stoppers as reactors. Gas production was determined by pressure measurement. The pressure was taken from the headspace of the reactors through the septum with a syringe connected to a digital pressure sensor with silicon measuring cell (ifm, type PN78, up to 2 bar). Biogas samples were also taken through the septum by a needle connected to a syringe. All the reactors were manually stirred once a day. After set-up of the reactors, Nitrogen was flushed to remove the air in the headspace of the bottles. Thereafter, all the reactors were incubated at $35^{\circ} \mathrm{C}$. Gas produced in each reactor was determined daily. Three blanks with water and inoculum were also tested to measure methane potential of inoculum. Results are expressed as means subtracting methane production from the blanks.

\subsubsection{Biochemical Methane Potential (BMP) Tests}

Each reactor was fed with $250 \mathrm{~g}$ of a mixture of inoculum and substrate with a $\mathrm{VS}_{\text {inoculum }} / \mathrm{VS}_{\text {substrate }}$ ratio of 2 to minimize diffusion limitation and to avoid acidification or toxicity inhibition. The headspace of each reactor was calculated by subtracting the volume of the mix inoculum-substrate from the volume of the reactor. As can be deducted from data in Table 1, the sample that required the highest amount of inoculum was CS. In this case, $246.7 \mathrm{~g}$ of inoculum and $3.3 \mathrm{~g}$ of CS were transferred to the reactors. On the contrary sample SL2 required $183.97 \mathrm{~g}$ of inoculum and $66.1 \mathrm{~g}$ of SL2.

\subsubsection{Co-Digestion Tests}

The co-digestion tests were also carried out in 500-mL serum bottles. First, co-digestion of manure with only one type of substrate (bi-substrate) was performed with a low inoculum-substrate ratio. For cheese whey co-di- 
Table 1. Characteristics of substrates and inoculum used in batch tests.

\begin{tabular}{|c|c|c|c|c|c|c|c|}
\hline Sample & $\begin{array}{l}\text { TS } \\
(\%)\end{array}$ & $\begin{array}{l}\text { VS } \\
(\%)\end{array}$ & $\begin{array}{l}\text { COD } \\
\left(\mathrm{g} \mathrm{L}^{-1}\right)\end{array}$ & $\begin{array}{l}\mathrm{NH}_{4}^{+}-\mathrm{N} \\
\left(\mathrm{g} \mathrm{kg}^{-1}\right)\end{array}$ & $\begin{array}{l}\text { NKT-N } \\
\left(\mathrm{g} \mathrm{kg}^{-1}\right)\end{array}$ & $\underset{\left(\mathrm{g} \mathrm{kg}^{-1}\right)}{\mathbf{P}_{\mathrm{T}}}$ & $\begin{array}{c}\text { Alkalinity } \\
\left(\mathrm{g} \mathrm{CaCO}_{3} \mathrm{~L}^{-1}\right)\end{array}$ \\
\hline CS & 95.5 & 87.4 & - & - & 3.8 & 3.7 & - \\
\hline SL1 & 8.0 & 6.2 & - & - & 4.8 & 1.0 & - \\
\hline SL2 & 4.0 & 3.2 & - & - & 2.3 & 0.5 & - \\
\hline DSL1 & 13.2 & 10.8 & - & - & 9.5 & 0.5 & - \\
\hline CW1 & 6.8 & 5.5 & 64.6 & 0.28 & 1.3 & 0.3 & 0.6 \\
\hline CW2 & 5.6 & 5.2 & 61.2 & 0.18 & 0.75 & 0.2 & 0 \\
\hline CW3 & 6.5 & 5.5 & 68.6 & 0.25 & 1.1 & 0.3 & 0 \\
\hline M & 11.5 & 9.3 & - & 0.78 & 4.8 & 0.6 & 21.1 \\
\hline Inoculum & 3.8 & 2.3 & 28.8 & 1.8 & 2.5 & 0.6 & 30.8 \\
\hline
\end{tabular}

gestion tests, mixtures with $10 \%, 20 \%$ and $30 \%$ of cheese whey based on mass were tested. For dairy sludges, batch trials were carried out with $40 \%$ of sludge and $60 \%$ of manure. Finally, cocoa shell and manure co-digestion tests were assayed at 5\% and 10\% CS based on mass. For these tests, $200 \mathrm{~g}$ of substrate mixture and $50 \mathrm{~g}$ of inoculum were used. The main objective of this trial was to assay the stability and limitations of co-digestion process.

Subsequently, the co-digestion tests were performed with different mixtures of manure and organic wastes (multi-substrate) with higher inoculums substrate ratios. The mixtures of wastes consisted of dairy sludges; dairy sludges and cheese whey; dairy sludges, cheese whey and cocoa shell, and finally a mixture with the wastes that yielded the highest amount of methane. For these tests, a $\mathrm{VS}_{\text {inoculum }} / \mathrm{VS}_{\text {substrate }}$ ratio of 1 was used.

\subsection{Analytical Techniques}

Biogas composition was measured on a 2 m Poropak T column in a HP 6890 GC System with helium as the carrier gas and a TCD detector. Methane volumes are expressed at standard conditions (STP: $\left.0^{\circ} \mathrm{C}, 1 \mathrm{~atm}\right)$. All other analyses (TS, VS, COD, Total Kjeldahl Nitrogen (TKN-N), Ammonia Nitrogen $\left(\mathrm{NH}_{4}^{+}-\mathrm{N}\right)$, and Total Phosphorous $\left(\mathrm{P}_{\mathrm{T}}\right)$ were performed according to Standard Methods [20].

\section{Results and Discussion}

\subsection{Characteristics of Substrates}

From data in Table 1, organic wastes can be classified in two types: Cocoa shell, which is a solid waste and the rest, which are liquid (cheese whey) or semi-liquid (manure and dairy sludges). The higher VS content of cocoa shell $(87.4 \%)$, compared with the other substrates (3.2\% - 10.8\%) potentially represents much higher energy content. However due to low water content, anaerobic digestion of cocoa shell alone would not be feasible unless it is diluted with water or co-digested with other substrate, such as manure. Regarding the rest of parameters, Nitrogen content of DSL1 could lead to ammonia inhibition [21]. Alkalinity is also an important parameter for anaerobic digestion. For these tests, alkalinity content of inoculum and manure seems to be enough to ensure stability of the process.

\subsection{BMP Test}

Methane and specific methane yields of organic wastes assayed in this work are shown in Figure 1. Cocoa shell had the highest methane yield, $195 \mathrm{~L} \mathrm{CH}_{4}$ per kg. The other wastes yielded considerably lower amounts of methane due to their lower solids content. Cheese whey samples yielded similar methane production values: 18.5, 17.5 and 19.3 $\mathrm{L} \mathrm{CH}_{4}$ per kg cheese whey for samples CW1, CW2 and CW3 respectively. Sludges from dairy factories gave different values, the best sample, in terms of methane potential was the SL1 (24.1 L CH $\left.\mathrm{kg}^{-1}\right)$, that corresponds with the sludge obtained from the fat separator of a dairy factory. The other sludge collected from the fat separator in other dairy factory (SL2) yielded a lower amount $\left(10.5 \mathrm{~L} \mathrm{CH}_{4} \mathrm{~kg}^{-1}\right)$, but the reason for this difference can be found in the VS content, 6.2\% for SL1 and 3.2\% for SL2. The biological dewatered sludge 


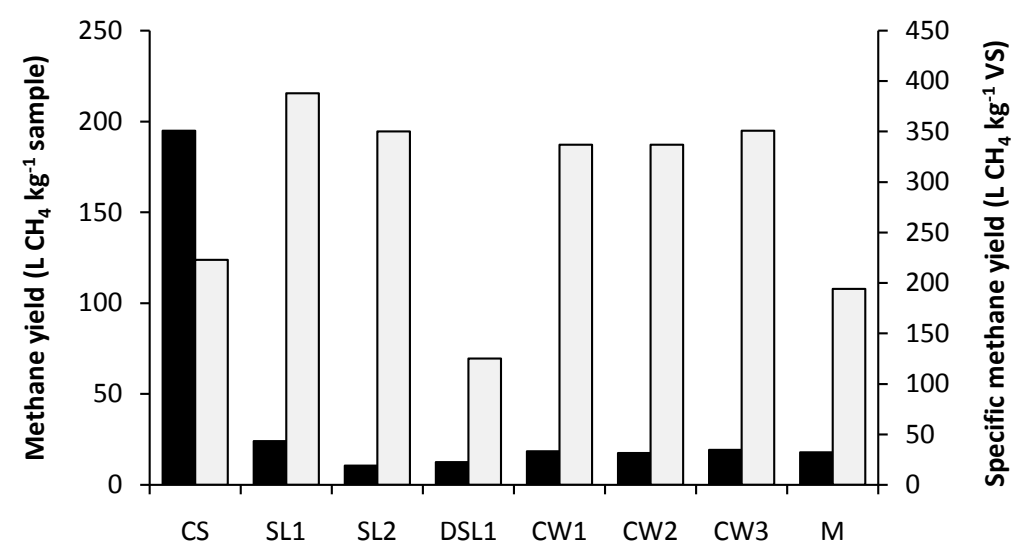

Figure 1. Methane and specific methane yields from organic wastes.

(DSL1) produced 12.6 $\mathrm{L} \mathrm{CH}_{4} \mathrm{~kg}^{-1}$. The methane yield for manure was a typical value for this kind of substrate, 18.0 $\mathrm{L} \mathrm{CH}_{4} \mathrm{~kg}^{-1}$.

By analyzing the specific methane yields, it can be observed that SL1, SL2 and the three cheese whey samples obtained the highest values, between 337 and $388 \mathrm{~L} \mathrm{CH}_{4} \mathrm{~kg}^{-1} \mathrm{VS}$. That indicates the high biodegradability of these substrates. The three cheese whey samples produced similar values: 337, 337 and $351 \mathrm{~L} \mathrm{CH}_{4} \mathrm{~kg}^{-1} \mathrm{VS}$ for CW1, CW2 and CW3 respectively. SL1 and SL2 yielded 388 and $350 \mathrm{~L} \mathrm{CH}_{4} \mathrm{~kg}^{-1}$ VS respectively. On the contrary, the dewatered biological sludge (DSL1) only yielded $125 \mathrm{~L} \mathrm{CH}_{4} \mathrm{~kg}^{-1}$ VS which is a low value compared with the other sludge samples. Its high Nitrogen content could be the reason for this low specific methane productivity. However, in BMP test the sample was highly diluted with the anaerobic inoculum to avoid toxicity effects which indicates that biodegradability of that sample was low. The reason for this low value can be that readily biodegradable organic matter was removed in the wastewater treatment plant, resulting in a dewatered sludge with a low specific methane yield. However, due to its high solids content (10.8\% VS), methane production per kg of sludge reached a value $\left(12.6 \mathrm{~L} \mathrm{CH}_{4} \mathrm{~kg}^{-1}\right)$ higher than that for SL2. The specific methane yield of cocoa shell (223 $\mathrm{L} \mathrm{CH}_{4} \mathrm{~kg}^{-1}$ VS) was low compared with SL1, SL2 and cheese whey samples, but higher than that of manure (194 $\mathrm{L} \mathrm{CH}_{4} \mathrm{~kg}^{-1} \mathrm{VS}$ ).

\subsection{Co-Digestion Tests}

\subsubsection{Bi-Substrate Co-Digestion Tests}

Based on individual methane potentials, the estimated methane yields of mixtures were assessed and compared with the experimental values. The sample 3 of cheese whey (CW3) was selected as the one with the highest methane potential. In Figure 2, cumulative methane yields of cheese whey and manure co-digestion trials are shown. Mixtures with 10\%, 20\% and 30\% cheese whey were tested. Since methane yields of cheese whey and dairy manure were similar, differences in methane yields of mixtures with $10 \%, 20 \%$ and $30 \%$ CW3 were small. Experimental values were close to theoretical values determined for individual substrates. Anaerobic co-digestion of cheese whey did not improve methane potential of manure, but co-digestion allowed digesting a difficult substrate such as the cheese whey without alkalinity addition.

Cumulative methane yields of cocoa shell and manure co-digestion trials are shown in Figure 3. For co-digestion of cocoa shell with manure, after 80 days both $5 \%$ and $10 \%$ samples did not reach their theoretical values based on individual trials. It can be observed that during the first 44 days, the methane production from sample with 5\% CS was higher than that for $10 \%$ CS sample. In addition, cumulative methane production was still increasing after 80 days. The methane yield of $5 \%$ CS sample (25.1 $\mathrm{L} \mathrm{CH}_{4} \mathrm{~kg}^{-1}$ mixture) was close to the theoretical value (26.8 $\mathrm{L} \mathrm{CH}_{4} \mathrm{~kg}^{-1}$ mixture) but for the $10 \% \mathrm{CS}$ sample the experimental value (30.5 $\mathrm{L} \mathrm{CH}_{4} \mathrm{~kg}^{-1}$ mixture) was further than the theoretical value ( $35.7 \mathrm{~L} \mathrm{CH}_{4} \mathrm{~kg}^{-1}$ mixture). The reason is that cocoa shell is a solid waste and anaerobic digestion is limited by hydrolysis of particulate matter. The higher cocoa shell ratio, the higher methane potential but hydrolysis step hinders the process at higher cocoa shell ratios. Moreover, dairy manure is a substrate with high suspended solids content and the amount of inoculum employed was also low 


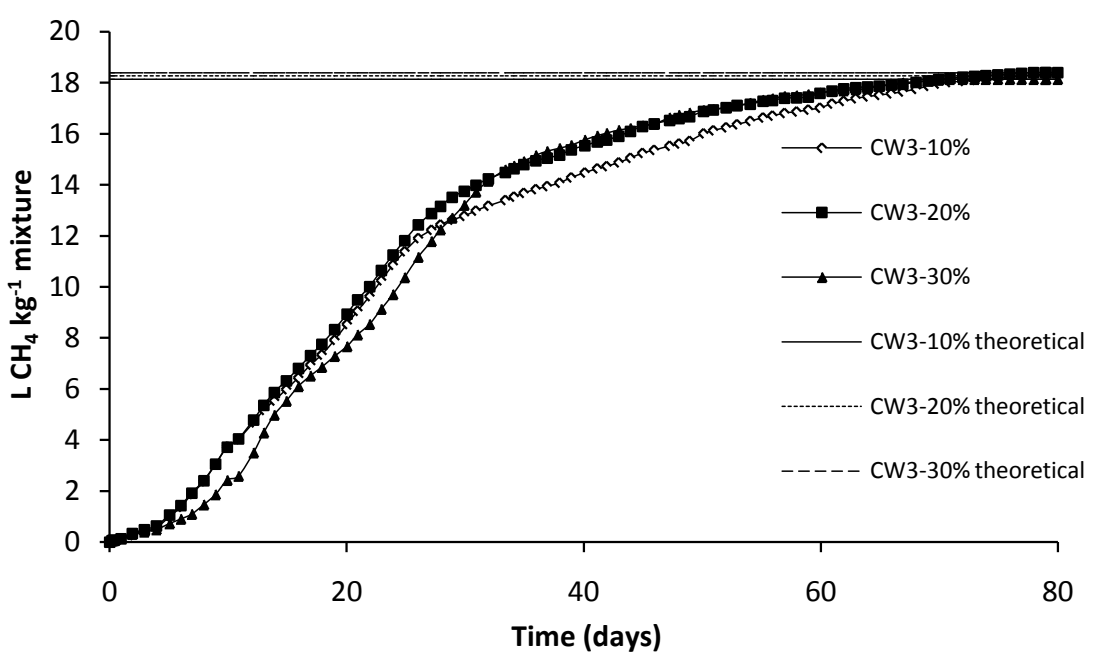

Figure 2. Cumulative methane production from co-digestion of mixtures of cheese whey and dairy manure.

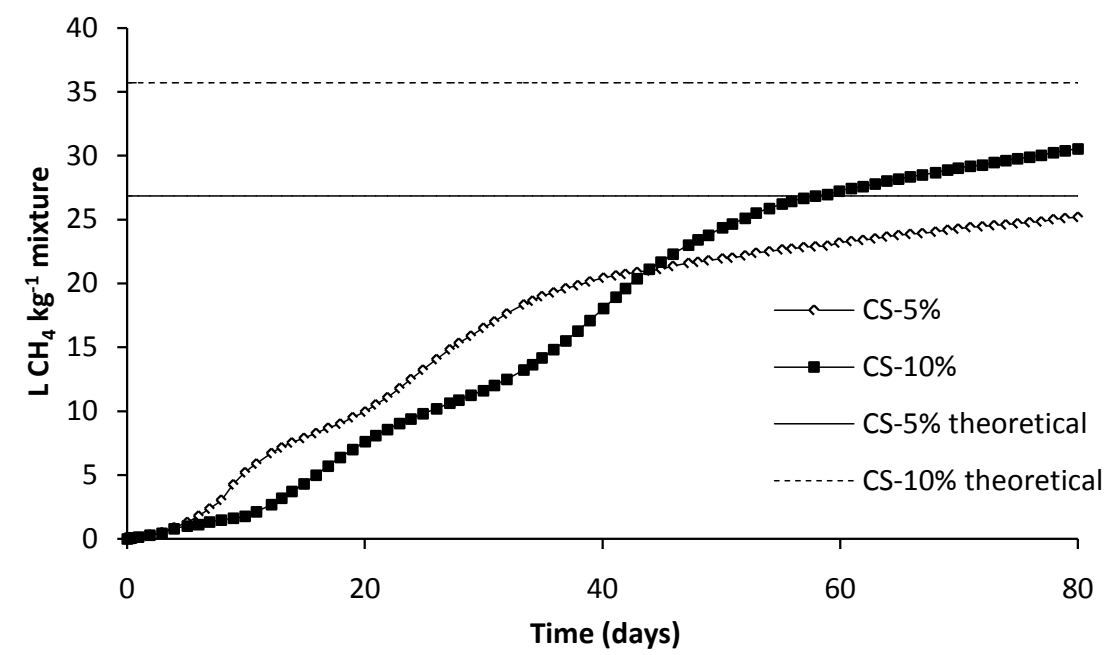

Figure 3. Cumulative methane production from co-digestion of mixtures of cocoa shell and dairy manure.

(20\% based on mass). Thermophilic anaerobic co-digestion at higher temperature could be an alternative to enhance the hydrolysis step. The high methane potential of cocoa shell allowed increasing the methane potential of manure.

The effect of higher cocoa shell ratio in the co-digestion process is depicted in Figure 4, where specific methane yields of both mixtures are shown. Methane yields of 124 and $68 \mathrm{~L} \mathrm{CH}_{4} \mathrm{~kg}^{-1}$ VS were obtained after 30 days of digestion for CS-5\% and CS-10\% respectively. This difference was reduced with time, but shows difficulties in anaerobic co-digestion of cocoa shell at $10 \%$ ratio as low methane production rates suggest.

Anaerobic co-digestion of dairy sludge and manure was performed at $40 \%$ sludge ratios based on mass. As Figure 5 shows, despite the high ratios of sludge, all the samples reached their theoretical yields based on individual methane yields. Co-digestion samples SL2-40\% and DSL1-40\% resulted in lower methane yields than manure due to the lower methane potentials of SL2 and DSL1. Co-digestion of manure with SL1 allowed increasing methane yield of manure alone, 20.6 $\mathrm{L} \mathrm{CH}_{4}$ per kg mixture compared to $18.0 \mathrm{~L} \mathrm{CH}_{4}$ per kg manure.

\subsubsection{Multi-Substrate Co-Digestion Tests}

Proportions of wastes in multi-substrate co-digestion tests are specified in Table 2. All the samples were composed of $60 \%$ dairy manure and $40 \%$ of a mixture of different wastes, based on mass. Sample 1 (S1) was com- 


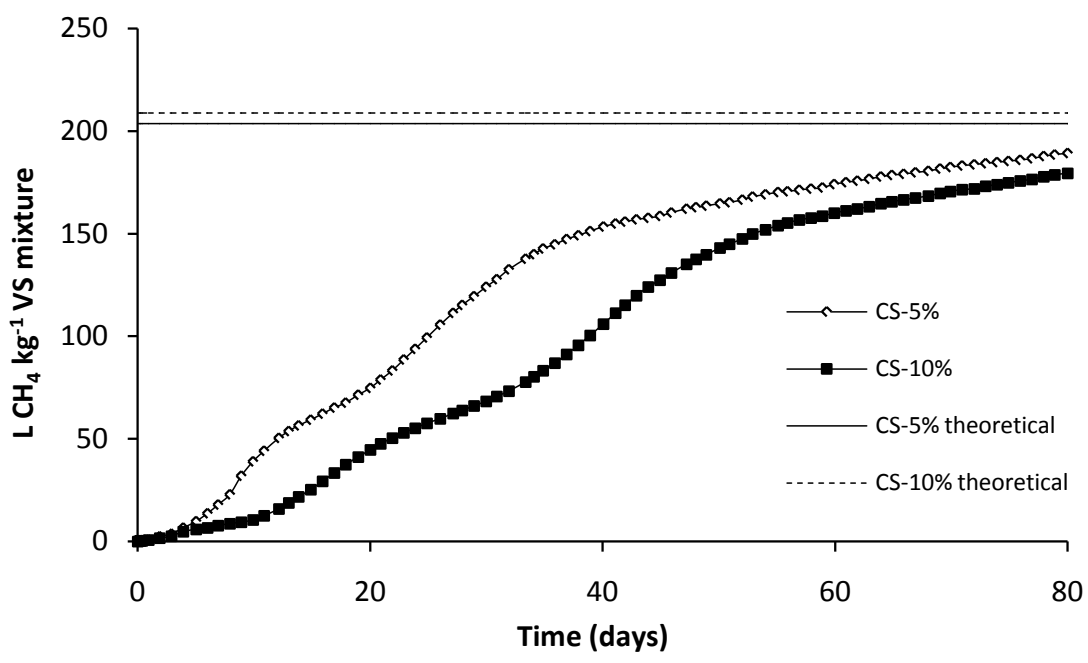

Figure 4. Cumulative specific methane production from co-digestion of mixtures of cocoa shell and dairy manure.

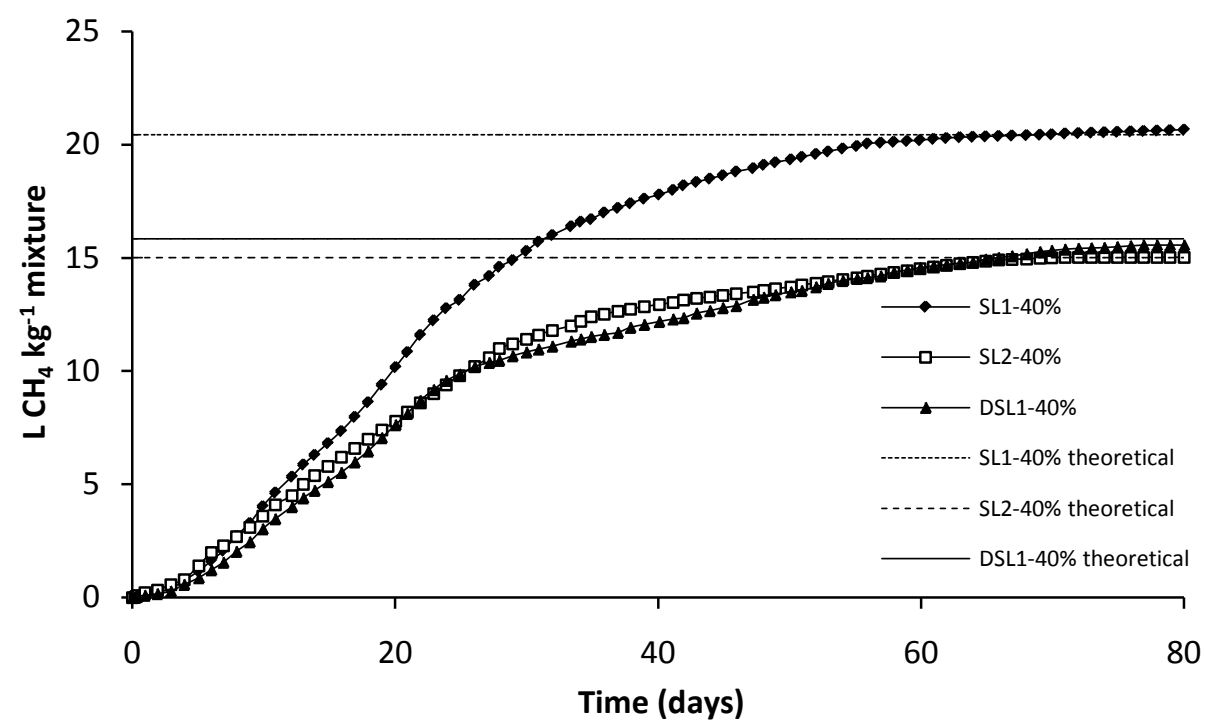

Figure 5. Cumulative methane production from co-digestion of mixtures of dairy sludge and dairy manure.

Table 2. Proportions of wastes used in multi-substrate mixtures.

\begin{tabular}{ccccccc}
\hline Sample & M (\%) & SL1 (\%) & SL2 (\%) & DSL1 (\%) & CW3 (\%) & CS (\%) \\
\hline S1 & 60 & 13.33 & 13.33 & 13.33 & - & - \\
S2 & 60 & 6.66 & 6.66 & 6.66 & 20 & - \\
S3 & 60 & 6 & 6 & 6 & 20 & 2 \\
S4 & 60 & 35 & - & - & - & 5 \\
\hline
\end{tabular}

posed of $60 \%$ of dairy manure and a mix of the three dairy sludges. For sample 2 (S2), cheese whey was included as co-substrate in the mixture. In sample 3 (S3), cocoa shell was added at 2\% mass ratio. Sample 4 (S4) was done with the aim to obtain a maximum methane yield. It was composed of 60\% dairy manure, 35\% SL1 and 5\% cocoa shell.

The methane yields for the different multi-substrate mixtures are presented in Figure 6. The highest methane yield was obtained by sample 4 that composed of manure (60\%), dairy sludge (SL1, 35\%) and cocoa shell (5\%) 


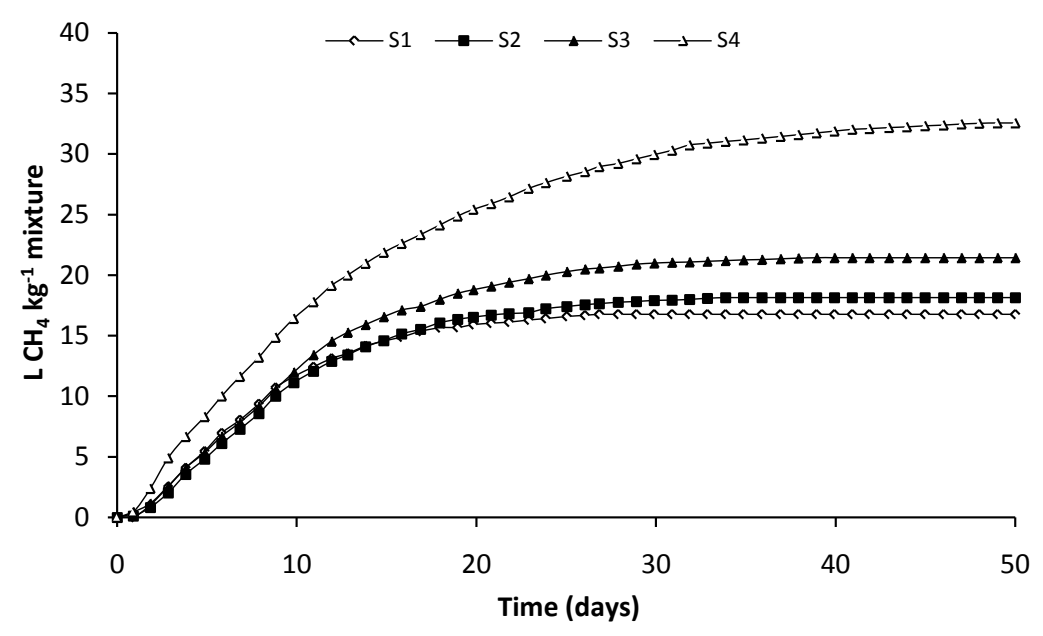

Figure 6. Cumulative methane production from multi-substrate co-digestion mixtures.

with a yield of $32.5 \mathrm{~L} \mathrm{CH}_{4} \mathrm{~kg}^{-1}$ mixture. Samples 1 (S1) and 2 (S2) obtained similar methane yields, 16.7 and $18.1 \mathrm{~L} \mathrm{CH}_{4} \mathrm{~kg}^{-1}$ mixture, respectively. Higher yield for sample 2 was caused by incorporation of cheese whey into the mixture. Compared to samples 1 and 2, sample 3 reached a higher yield (21.4 $\mathrm{L} \mathrm{CH}_{4} \mathrm{~kg}^{-1}$ mixture) due to the presence of cocoa shell.

This trial provides good evidence that all the wastes studied are suitable for anaerobic co-digestion with dairy manure. In terms of methane potential, wastes from dairy industry (cheese whey and dairy sludges) did not improve methane yield from manure, except the sludge sample SL1. In this sense, sludges collected from fat separation facilities exhibited high specific methane yields, between 350 and $388 \mathrm{~L} \mathrm{CH}_{4} \mathrm{~kg}^{-1} \mathrm{VS}$. In spite of low methane yields, anaerobic co-digestion of organic wastes from dairy industry with dairy manure would be a good management strategy. Regarding cocoa shell, it is an interesting waste for anaerobic co-digestion that can considerably improve methane yield due to its high VS content. However, at proportions of $10 \%$ cocoa shell the process was hindered by hydrolysis of particulate matter. Anaerobic digestion at higher temperatures (thermophilic range) could be a better option for this kind of waste.

\section{Conclusion}

It has been shown that the wastes tested constitute a good substrate for anaerobic co-digestion with dairy manure. On the one hand, the management of these wastes would cease to be a problem. On the other hand, by means of anaerobic digestion their resources could be recovered to produce biogas, contributing to reducing the dependence from fossil fuels. Liquid and semi-liquid wastes from dairy industry showed methane potentials in the same range as dairy manure. On the contrary, cocoa shell has demonstrated to be a substrate with methane potential much higher than that of manure. In mesophilic conditions, anaerobic co-digestion with $5 \%$ cocoa shell and 35\% dairy sludge based on mass allowed increasing $80.5 \%$ methane yields of manure alone.

\section{Acknowledgments}

We acknowledge the technical staff of Teican Medioambiental for their contribution to this work. This research was supported by Iberdrola Renovables and Ocyener in the framework of the Concurso Eólico in the Autonomous Community of Cantabria.

\section{References}

[1] Lesschen, J.P., van den Berg, M., Westhoek, H.J., Witzke, H.P. and Oenema, O. (2011) Greenhouse Gas Emission Profiles of European Livestock Sectors. Animal Feed Science and Technology, 166, 16-28. http://dx.doi.org/10.1016/j.anifeedsci.2011.04.058

[2] Vander Zaag, A.C., MacDonald, J.D., Evans, L., Vergé, X.P.C. and Desjardins, R.L. (2013) Towards an Inventory of Methane Emissions from Manure Management That Is Responsive to Changes on Canadian Farms. Environmental 
Research Letters, 8, 13 p.

[3] Ball Coelho, B., Murray, R., Lapen, D., Topp, E., Bruin, A. and Khan, B. (2012) Phosphorus and Sediment Loading to Surface Waters from Liquid Swine Manure Application under Different Drainage and Tillage Practices. Agricultural Water Management, 104, 51-61. http://dx.doi.org/10.1016/j.agwat.2011.10.020

[4] De Vries, J.W., Groenestein, C.M. and De Boer, I.J.M. (2012) Environmental Consequences of Processing Manure to Produce Mineral Fertilizer and Bio-Energy. Journal of Environmental Management, 102, 173-183. http://dx.doi.org/10.1016/j.jenvman.2012.02.032

[5] Nasir, I.M., Mohd Ghazi, T.I. and Omar, R. (2012) Anaerobic Digestion Technology in Livestock Manure Treatment for Biogas Production: A Review. Engineering in Life, 12, 258-269. http://dx.doi.org/10.1002/elsc.201100150

[6] Holm-Nielsen, J.B., Al Seadi, T. and Oleskowicz-Popiel, P. (2009) The Future of Anaerobic Digestion and Biogas Utilization. Bioresource Technology, 100, 5478-5484. http://dx.doi.org/10.1016/j.biortech.2008.12.046

[7] Cuéllar, A.D. and Webber, M.E. (2008) Cow Power: The Energy and Emissions Benefits of Converting Manure to Biogas. Environmental Research Letters, 3, 8 p.

[8] Abbasi, T., Tauseef, S.M. and Abbasi, S.A. (2012) Anaerobic Digestion for Global Warming Control and Energy Generation. An Overview. Renewable and Sustainable Energy Reviews, 16, 3228-3242. http://dx.doi.org/10.1016/j.rser.2012.02.046

[9] Chen, Y., Cheng, J.J. and Creamer, K.S.(2008) Inhibition of Anaerobic Digestion Process: A Review. Bioresource Technology, 99, 4044-4064. http://dx.doi.org/10.1016/j.biortech.2007.01.057

[10] Ergüder, T., Tezel, U., Güven, E. and Demirer, G.N. (2001) Anaerobic Biotransformation and Methane Generation Potential of Cheese Whey in Batch and UASB Reactors. Waste Management, 21, 643-650. http://dx.doi.org/10.1016/S0956-053X(00)00114-8

[11] Palatsi, J., Viñas, M., Guivernau, M., Fernandez, B. and Flotats, X. (2011) Anaerobic Digestion of Slaughterhouse Waste: Main Process Limitations and Microbial Community Interactions. Bioresource Technology, 102, 2219-2227. http://dx.doi.org/10.1016/j.biortech.2010.09.121

[12] Dinuccio, E., Balsari, P., Gioelli, F. and Menardo, S. (2010) Evaluation of the Biogas Productivity Potential of Some Italian Agro-Industrial Biomasses. Bioresource Technology, 101, 3780-3783. http://dx.doi.org/10.1016/j.biortech.2009.12.113

[13] Hejnfelt, A. and Angelidaki, I. (2009) Anaerobic Digestion of Slaughterhouse By-Products. Biomass and Bioenergy, 33, 1046-1054. http://dx.doi.org/10.1016/j.biombioe.2009.03.004

[14] Rico, J.L., García, H., Rico, C. and Tejero, I. (2007) Characterisation of Solid and Liquid Fractions of Dairy Manure with Regard to Their Component Distribution and Methane Production. Bioresource Technology, 98, 971-979. http://dx.doi.org/10.1016/j.biortech.2006.04.032

[15] Weiland, P. (2006) Biomass Digestion in Agriculture: A Successful Pathway for the Energy Production and Waste Treatment in Germany. Engineering in Life Sciences, 6, 302-309. http://dx.doi.org/10.1002/elsc.200620128

[16] Khalid, A., Arshad, M., Anjum, M., Mahmood, T. and Dawson, L. (2011) The Anaerobic Digestion of Solid Organic Waste. Waste Management, 31, 1737-1744. http://dx.doi.org/10.1016/j.wasman.2011.03.021

[17] Alfonso, D., Brines, N., Peñalvo, E., Vargas, C., Pérez Navarro, A., Gómez, P., Pascual, A. and Ruiz, B. (2010) Cuantificación de materias primas para producción de biogás (PSE-Probiogas). http://213.229.136.11/bases/ainia_probiogas.nsf/0/FEB62601BC95C8D6C125773D00394446/\$FILE/Resumen_inf_cu antificacion.pdf.

[18] Villar, A. (2005) Situación y perspectivas de la gestión de los sueros de quesería generados en Cantabria (Centro de Investigación y Formación Agraria de Cantabria). http://www.cifacantabria.com/Documentacioncifa/download.php?sess=0\&parent=18\&expand=1\&order=name\&binary $=1 \& i d=13$ ).

[19] Rico, C., Rico, J.L., Tejero, I., Muñoz, N. and Gómez, B. (2011) Anaerobic Digestion of the Liquid Fraction of Dairy Manure in Pilot Plant for Biogas Production: Residual Methane Yield of Digestate. Waste Management, 31, 2167-2173. http://dx.doi.org/10.1016/j.wasman.2011.04.018

[20] APHA (1998) Standard Methods for the Examination of Water and Wastewater. 18th Edition, American Public Health Association, Washington, DC.

[21] Bhattacharya, S.K. and Parkin, G.F. (1989) The Effect of Ammonia on Methane Fermentation Processes. JournalWater Pollution Control Federation, 61, 55-59. 